Sobolewska-Samorek Agnieszka, Zarzycka Danuta, Trojanowska Alina, Brodowicz-Król Magdalena, Dońka Katarzyna, Szewczyk Monika, Hordyjewska Anna, Warowna Marlena, Sikora Kamil, Luczyk Robert, Luczyk Marta. New insight of parenteral nutrition in children - short review. Journal of Education, Health and Sport. 2020;10(6):56-67. eISSN 2391-8306. DOI http://dx.doi.org/10.12775/JEHS.2020.10.06.006

https://apcz.umk.pl/czasopisma/index.php/JEHS/article/view/JEHS.2020.10.06.006

https://zenodo.org/record/3884500

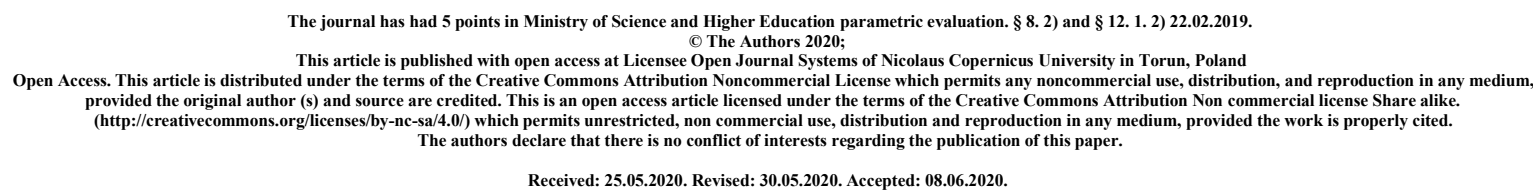

New insight of parenteral nutrition in children - short review

Agnieszka Sobolewska-Samorek ${ }^{1}$, Danuta Zarzycka ${ }^{1}$, Alina Trojanowska ${ }^{1}$, Magdalena Brodowicz-Król' ${ }^{1}$, Katarzyna Dońka', Monika Szewczyk², Anna Hordyjewska ${ }^{3}$, Marlena Warowna ${ }^{4}$, Kamil Sikora ${ }^{5}$, Robert Jan Luczyk ${ }^{6}$, Marta Luczyk ${ }^{7}$

${ }^{1}$ Chair and Department of Pediatric Nursing, Medical University of Lublin, Poland ${ }^{2}$ Chair of Surgery and Nursing Surgery, Medical University of Lublin, Poland ${ }^{3}$ Chair and Department of Medical Chemistry, Medical University of Lublin, Poland

${ }^{4}$ Department of Dermatology, Cosmetology and Aesthetic Surgery, Jan Kochanowski

University in Kielce, Poland

${ }^{5}$ Student of the Faculty of Health Sciences, Medical University of Lublin, Poland ${ }^{6}$ Chair of Internal Medicine with the Department of Internal Nursing, Faculty of Health

Sciences, Medical University of Lublin, Poland

${ }^{7}$ Chair of Oncology and Environmental Health, Faculty of Health Sciences, Medical University of Lublin, Poland

\begin{abstract}
Admission. Parenteral nutrition (parenteral) is the supply of all essential nutrients - proteins, carbohydrates, fats, electrolytes, vitamins, trace elements and water intravenously. Parenteral nutrition is a generally available method of nutritional treatment used when the supply of food through the gastrointestinal tract is impossible, insufficient or contraindicated. Complete parenteral nutrition should be replaced as soon as possible with feeding to the gastrointestinal tract. Chronic diseases in children are often complicated by serious nutritional deficiencies.
\end{abstract}

Key words: parenteral nutrition, newborns, children, carbohydrates, lipids, amino acids 


\section{Parenteral nutrition}

The need for parenteral nutrition in children usually occurs for reasons primarily associated with intestinal insufficiency. The most common cause of chronic parenteral nutrition is short bowel syndrome [1,2]. The short bowel syndrome in children may occur as a result of resection, among others in the course of necrotic enteritis, tumors or gastrointestinal malformations or small intestinal atresia. This disease is characterized by anatomical or functional loss of more than $50 \%$ of the small intestine. It is a congenital defect of the gastrointestinal tract, which is one of the more common causes of gastrointestinal obstruction $[2,3,4,5]$.

Other illnesses that induce parenteral nutrition include diseases that occur with intestinal motility disorders, such as Hirschprung's disease or pseudointic obstructive syndrome. As a result of these diseases, malabsorption occurs due to diarrheas which cannot be treated $[3,6$,$] .$

A much smaller group of patients requiring chronic parenteral nutrition are children burdened with diseases resulting from parenteral causes such as metabolic or cystic fibrosis [4, 7, 8]. Other causes of chronic parenteral nutrition include complications of chemotherapy, acute pancreatitis, catabolism associated with trauma, surgery or burns, and prematurity. In preterm infants, the indication for feeding are: parenteral immaturity of the digestive tract and necrotizing enterocolitis [3, 7] (Fig. 1).

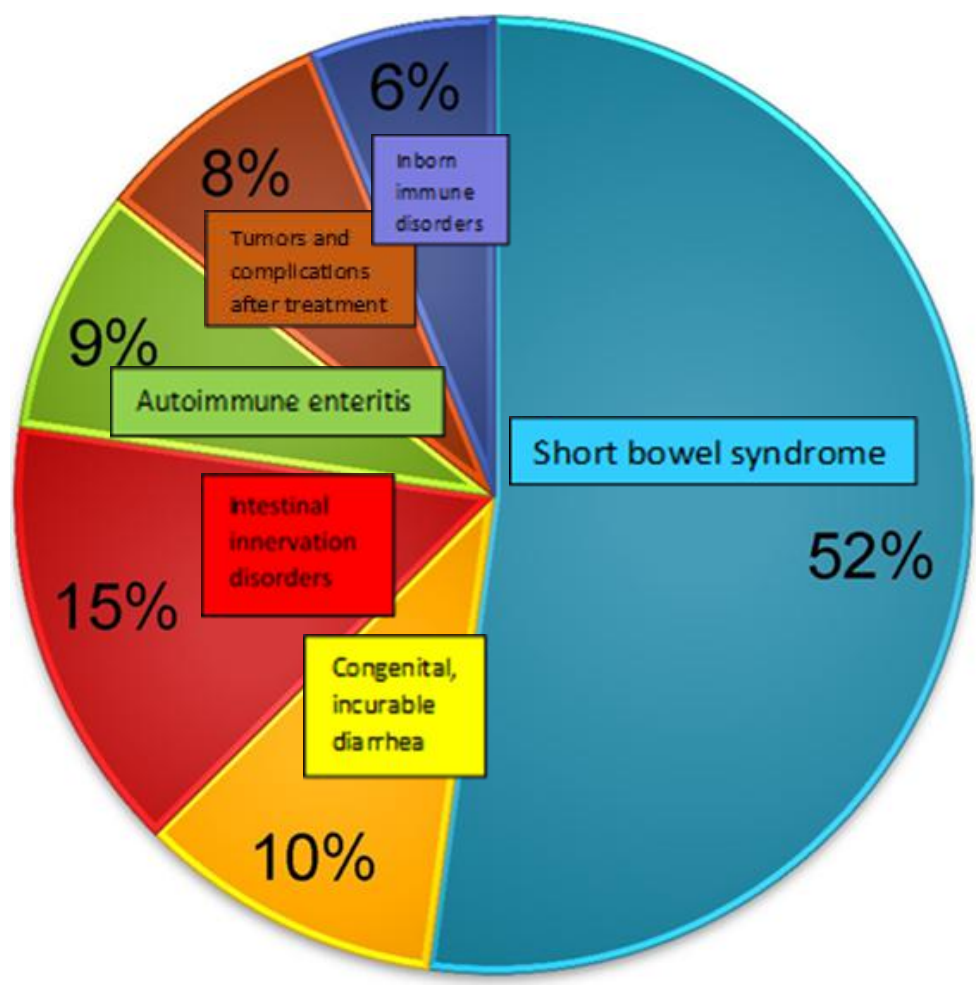

Figure 1. Indications for chronic parenteral nutrition in children $[2,3,4,6,7,8]$.

\section{Amino acids in parenteral nutrition}

Amino acid preparations used in parenteral nutrition of children, especially newborns, are most often modeled on the amino acid composition of human milk, umbilical cord blood or derived from pharmacokinetic studies in newborns [1,9]. Nine amino acids have been recognized as essential in newborns. They are valine, isoleucine, leucine, threonine, methionine, tryptophan, phenylalanine, lysine, histidine $[5,10]$. In the case of neonates with a low birth weight, essential amino acids include both arginine, which has a positive effect on 
reducing the risk of necrotic enteritis, and cysteine and taurine, which are important for the proper development of the central nervous system [11, 12].

Amino acids are recommended to be included in parenteral nutrition, in the first 2 hours of life in a dose dependent on the birth weight of the child $[6,9,13]$. The starting dose of amino acids for newborns with a birth weight higher than $1500 \mathrm{~g}$ should start from $2.0 \mathrm{~g} / \mathrm{kg}$ of body weight per day $[2,12]$. The dose should be increased in the following days by 0.5 $\mathrm{g} / \mathrm{kg}$ of body weight per day until $3.5 \mathrm{~g} / \mathrm{kg}$ of body weight per day. On the other hand, neonates with a birth weight of less than $1500 \mathrm{~g}$ should start with a dose of $2.5 \mathrm{~g} / \mathrm{kg}$ of body weight per day, gradually increasing the supply to $4.0-4.1 \mathrm{~g} / \mathrm{kg}$ of body weight per day, until reaching a weight of $1500 \mathrm{~g}$ (Tab.1). This is to ensure not only proper growth after birth, but also to supplement residual energy reserves $[13,14]$. In the case of newborns additionally burdened with diseases of particular organs or systems, amino acid preparations adapted to individual clinical situations are also available. Preparations containing less phenylalanine, methionine and tryptophan, and more branched chain amino acids are recommended for patients with hepatic insufficiency [3, 8]. Amino acid solutions containing glycine-L-tyrosine should be selected in patients with renal insufficiency $[15,16]$.

Table 1. Supplying of amino acids in parenteral nutrition $[2,12,13,14]$.

\begin{tabular}{|c|c|c|}
\hline Amino acid dose & $\begin{array}{l}\text { Newborn with birth weight } \\
\text { above } 1500 \mathrm{~g}\end{array}$ & $\begin{array}{l}\text { Newborn with birth weight } \\
\text { under } 1500 \mathrm{~g}\end{array}$ \\
\hline Output/Initial dose & $2 \mathrm{~g} / \mathrm{kg}$ of body weight/24h & $2,5 \mathrm{~g} / \mathrm{kg}$ of body weight $/ 24 \mathrm{~h}$ \\
\hline Final dose & $3,5 \mathrm{~g} / \mathrm{kg}$ of body weight $/ 24 \mathrm{~h}$ & $\begin{array}{c}4,0-4,1 \mathrm{~g} / \mathrm{kg} \text { of body } \\
\text { weight } / 24 \mathrm{~h}\end{array}$ \\
\hline
\end{tabular}

\section{Fats in parenteral nutrition}

Fats are a high energy substrates. The supply of lipids in parenteral nutrition should cover from 25 to $40 \%$ of the extra-cerebral energy needs [17, 18]. Newborns born prematurely, especially those with very low birth weight less than $1500 \mathrm{~g}$, are particularly sensitive to deficiency in nutrition, because they have less fat in the body compared to the newborns $[18,19,20]$. In premature babies, the 2 or 3-day limitation of fat supplying causes the emergence of a clinical condition known as a deficiency of essential fatty acids. To avoid this disorder, premature babies should receive fat from the first day of life [7]. The total fat supplying should be about 3-4 g/kg of body weight per day (Tab. 2) [17, 20, 21]. Preparations containing a higher dose of phospholipids may increase the risk of hyperlipidemia [5, 20, 22]. In European Union, three types of lipid emulsions are registered for children [6, 23]. The first type is based solely on soybean oil. It is characterized by a high content of polyunsaturated omega- 6 fatty acids and a relatively low omega -3 fatty acids content. Such composition may involve the risk of overproduction of pro-inflammatory cytokines and may increase oxidative stress [3, 8, 24]. Soybean oil can suppress the cells of the immune system, and the phytosterols present in it can contribute to the occurrence of cholestasis - one of the complications of parenteral nutrition $[8,11,25,26]$. The second type of lipid emulsion consists the soybean oil and the olive oil. The olive oil contains two times more of $\alpha$ tocopherol and much less of polyunsaturated fatty acids as compared to soybean oil [20].

The third emulsion is a combination of soybean oil with MCTs oil (medium-chain triglyceride fatty acids derived from coconut oil). MCTs, as a result of better solubility and more efficient intravascular metabolism, are faster purified from plasma [17, 21, 27].

Pediatric patients receiving fat emulsions should periodically monitor the serum triglyceride levels $[6,23,26,28]$. It is also recommended to avoid excessive supplying of lipids in children diagnosed with acute respiratory failure, because the supply of emulsion may deteriorate the child's respiratory efficiency [4, 29]. However, lipids should not be 
avoided in parenteral nutrition because complete cessation of their supplying may carry a risk of a deficiency of free fatty acids $[1,6,30]$. The use of lipid preparations containing omega-3 fatty acids from fish oil significantly reduces the incidence of cholestasis and hepatic complications in children, dependent on parenteral nutrition [17, 20,21].

Table 2. Lipids dose in parenteral nutrition [18, 19, 20].

\begin{tabular}{|l|c|c|}
\hline Lipids dose & $\begin{array}{l}\text { Newborn with birth weight } \\
\text { above 1500g }\end{array}$ & $\begin{array}{l}\text { Newborn with birth weight } \\
\text { under 1500g }\end{array}$ \\
\hline Output/Initial dose & \multicolumn{2}{|c|}{$0,5 \mathrm{~g} / \mathrm{kg}$ of body weight $/ 24 \mathrm{~h}$} \\
\hline Final dose & $\begin{array}{c}3-4 \\
\mathrm{~g} / \mathrm{kg} \text { of body weight } / 24 \mathrm{~h}\end{array}$ & $\begin{array}{c}2,5-3 \\
\mathrm{~g} / \mathrm{kg} \text { of body weight } / 24 \mathrm{~h}\end{array}$ \\
\hline
\end{tabular}

\section{Carbohydrates in parenteral nutrition}

Carbohydrates are the main source of energy and should cover $40-60 \%$ of the child's energy needs [31]. Carbohydrate administration provides the energy, reduces gluconeogenesis, ensures optimal consumption of amino acids needed for protein synthesis and regulation of fat metabolism [32]. The basic carbohydrate used in parenteral nutrition is glucose. It is a source of energy for all tissues of the body, especially for the brain, spinal cord, kidneys and erythrocytes [8, 33, 34]. In parenteral nutrition, it should provide $60-75 \%$ of non-protein calories. The supplying of glucose in parenteral nutrition should ensure normoglycemia [35, 36].

Excessive supplying of glucose inhibits fat oxidation, stimulates lipogenesis, increases fat deposition in tissues, leading to fatty hepatic steatosis and hyperglycaemia. Excessive glucose also increases production of $\mathrm{CO}_{2}$ and directly effects on the acceleration of lung ventilation $[1,31,34]$. Newborns with very small and extremely low body weight are at risk for hypoglycaemia [2, 5]. Therefore, it is necessary to start the infusion of glucose as soon as possible and ensure its serum concentration above $40-50 \mathrm{mg} / \mathrm{dl}$. European recommendations for parenteral nutrition for children advise the inclusion of glucose in parenteral nutrition during the first 2 hours of life. The purpose of this procedure is to prevent hypoglycaemia, i.e. blood glucose levels below $40 \mathrm{mg} \%$. The risk of such low glycemia in small premature babies is high due to insufficient glycogen reserves [31, 36, 37]. The initial dose of glucose should be $8-10 \mathrm{~g} / \mathrm{kg}$ of body weight per day and should be increased in subsequent days (Tab. 3) [35, 38]. In the first days of life, it is necessary to monitor blood glucose every 3-4 hours $[31,39]$. In children with very low birth weight, glucose intolerance may occur, which is an indication for the use of a constant infusion of insulin in order to maintain normoglycemia [6, 31]. Hyperglycaemia, should be prevented because it causes the increase of serum osmolality, osmotic diuresis and water-electrolyte disturbances [37, 40]. Hyperglycemia is associated with increased mortality, as well as an increased incidence of peri-ventricular and intraventricular bleeding, retinopathy of pre-term infants and sepsis [34]. Glucose concentrations during to parenteral nutrition with dose over of 150-180 mg/dl are considered to cause the hyperglycemia $[8,31]$. 
Table 3. Glucose dose in parenteral nutrition [7, 35, 38].

\begin{tabular}{|l|c|c|}
\hline Glucose dose & Output/Initial dose & Final dose \\
\hline Newborn & $\mathrm{g} / \mathrm{kg}$ of bodyweight $/ 24 \mathrm{~h}$ & $17 \mathrm{~g} / \mathrm{kg}$ of body weight $/ 24 \mathrm{~h}$ \\
\hline
\end{tabular}

\section{Vitamins in parenteral nutrition}

Newborns with very low birth weight have low endogenous systemic resources of microelements and vitamins [8]. Vitamin A is one of the great importance in the development of connective and cartilage tissues. Its presence affects the rate of formation of mucopolysaccharides, which are the basic component of connective tissue $[5,8,41]$.

Vitamin A plays an important role in the development of the lungs, in the functioning of the immune system and in the visual processes. It takes part in the regeneration of the epithelium in the process of convalescing of premature's with bronchopulmonary dysplasia (BPD - brocho pulmonary dysplasia) [2, 42]. Newborn babies born prematurely have low levels of vitamin A in the blood serum and small amounts of it in the liver compared to newborns born at the time $[8,43]$. During parenteral nutrition, the supplying of vitamin A is about $40 \%$, as a result of its disintegration under the influence of light and the drainage of walls. The recommended dose of vitamin A ranges from 500-1500 IU/kg of body weight per day. The supply of this vitamin should be started from the second day of life. ( $80 \mathrm{ml} / \mathrm{kg}$ of body weight per day) (Tab.4) [7, 44]. Usually, the supply of that vitamin at its upper limits is insufficient to compensate for its deficiencies, especially in premature infants with low birth weight $<1000 \mathrm{~g}[8,42,44]$.

The optimal range of vitamin D concentration is $30-50 \mathrm{ng} / \mathrm{ml}$. Values below 20 $\mathrm{ng} / \mathrm{ml}$ indicate a deficiency of cholecalciferol. In children remaining on total parenteral nutrition, the supply of vitamin D is $160 \mathrm{IU} / \mathrm{kg}$ of body weight per day. Newborn babies born prematurely with cholestasis, due to the reduced amount of bile in the small intestine have impaired synthesis and absorption of vitamin $\mathrm{D}$ in the liver, should receive vitamin at a minimum dose of $2-5 \mu \mathrm{g} / \mathrm{kg}$ of body weight per day [7, 41,45, 46].

Tocopherol (vitamin E) is considered the most important natural antioxidant that protects cell membranes against destabilization and breakdown in the process associated with lipid peroxidation. It also protects the membranes of erythrocytes from damage associated with the oxidation of unsaturated fatty acids, which are the part of the membrane. Supplementation with vitamin $\mathrm{E}$ in preterm infants reduces the frequency of intraventricular hemorrhage and the number of severe cases of retinopathy of prematurity (ROP) and increases level of hemoglobin [7, 44]. In parenteral nutrition, doses $2.8-3.5 \mathrm{mg} / \mathrm{kg}$ of body weight per day of vitamin $\mathrm{E}$ are used (Tab.4). Higher tocopherol concentrations may increase the risk of sepsis and necrotizing enterocolitis [7, 8, 44].

Vitamin K plays an important role in the synthesis of coagulation factors (like: factors II, VII, IX, X), anti-thrombotic proteins (like: protein C, S and Z) and osteocalcin. In some cases, usually in the first week of life, a deficiency of vitamin $\mathrm{K}$ can lead to serious bleeding disorders in the newborn, and to the so-called newborn hemorrhagic disease (VKDB - Vitamin K Deficiency Bleeding) [1, 47,48]. Demand for vitamin K in premature infants was set at $10 \mu \mathrm{g} / \mathrm{kg}$ of body weight per day. In the prophylaxis of vitamin $\mathrm{K}$ deficiency in premature infants with birth weight less than $1500 \mathrm{~g}$, vitamin $\mathrm{K}$ is used intramuscularly or intravenously at $0.3 \mathrm{mg}$. In contrast, for children with a birth weight above $1500 \mathrm{~g}$ only 
intramuscularly administration of vitamin $\mathrm{K}$ at dose of $0.5 \mathrm{mg}$ is recommended. Vitamin $\mathrm{K}$ is administered intramuscularly every 6 weeks because after this administration the proper vitamin $\mathrm{K}$ concentration is maintained for 4 - 6 weeks (Tab. 4). The healing intravenous dose of vitamin $\mathrm{K}$ is reserved for the treatment of coagulation disorders in newborns and infants who have prolonged prothrombin time (increased INR). After intravenous administration, the half-life of the vitamin is very short and lasts only 24 hours [8, 49]. Parenteral nutrition accounts for as much as $80 \%$ of the total supplying of vitamin $\mathrm{K}$ in premature infants born below the $28^{\text {th }}$ week of pregnancy in the first two weeks of life. In premature newborns, it is recommended to administer vitamin $\mathrm{K}$ at a dose of $10 \mu \mathrm{g} / \mathrm{kg} / \mathrm{day}$. Vitamin $\mathrm{K}$ contains preparations of fat-soluble vitamins and fat emulsions based on soybean oil $[6,49,50]$.

Table 4. Vitamins dose in parenteral nutrition $[7,41,45,46]$.

\begin{tabular}{|c|c|c|c|c|}
\hline Vitamins & $\mathbf{A}$ & D & $\mathbf{E}$ & $\mathbf{K}$ \\
\hline \multirow{2}{*}{ Newborn } & \multirow{2}{*}{$\begin{array}{c}500-1500 \mathrm{IU} / \mathrm{kg} \\
\text { of body } \\
\text { weight } / 24 \mathrm{~h}\end{array}$} & \multirow{2}{*}{$\begin{array}{c}160 \mathrm{IU} / \mathrm{kg} \text { of } \\
\text { body weight/24h }\end{array}$} & \multirow{2}{*}{$\begin{array}{c}2,8-3,5 \mathrm{mg} / \mathrm{kg} \\
\text { of body } \\
\text { weight } / 24 \mathrm{~h}\end{array}$} & $\begin{array}{c}\text { for newborn with } \\
\text { birth weight under } \\
1500 \mathrm{~g} \text { - } \\
0,3 \mathrm{mg} / \mathrm{kg} \text { of body } \\
\text { weight/every } 6 \\
\text { week }\end{array}$ \\
\hline & & & & $\begin{array}{c}\text { for newborn with } \\
\text { birth weight above } \\
1500 \mathrm{~g}- \\
0,5 \mathrm{mg} / \mathrm{kg} \text { of body } \\
\text { weight/every } 6 \\
\text { week }\end{array}$ \\
\hline
\end{tabular}

\section{Mineral ingredients in parenteral nutrition}

Minerals are essential for the proper functioning of the human body. They play many important functions mainly in metabolic processes. In the disturbance of their homeostasis, the changes and abnormal cell's functioning occur. Due to the need for individual mineral components, we divide them into microelements and macroelements $[8,51$, $52,53]$.

\section{Macroelements}

In the last trimester of pregnancy, very intensive growth and mineralization of the fetal skeletal occurs. During this period the fetus accumulates minerals in the amount of approx. $90-150 \mathrm{mg} / \mathrm{kg} /$ day of calcium $(\mathrm{Ca})$ and $50-85 \mathrm{mg} / \mathrm{kg} /$ day of phosphorus $(\mathrm{P})$. This is related to the child's weight gain $[1,6,51,54,55]$. The dietary requirement of calcium is as follows: in infants 400-600 mg/day, in children about $800 \mathrm{mg} /$ day, in young people 1200 $\mathrm{mg}$ /day and over 25 years of age - about $800 \mathrm{mg} /$ day. In women during pregnancy and lactation it is about $1200 \mathrm{mg} /$ day (Tab.5). As a reference point in parenteral nutrition, the fetal development period and the supply of calcium and phosphorus at a similar level are taken into account $[2,53]$. The higher supplying of amino acids and, therefore, expected increasing of body mass, the higher calcium and phosphates should be supplying. The supply of calcium should be started from the age of 1 year to prevent early hypocalcemia while the supply of phosphates should start from 2-3 days of age. The best absorption of calcium and phosphate is when their ratio in food is - $\mathrm{Ca}: \mathrm{P}=1.3-1.7: 1$. The presence of lactose and some amino acids 
improve the absorption of calcium, while excess of fats, phytates, and oxalates inhibit this process $[2,51,54]$.

Magnesium (Mg) is the second most abundant intracellular cation. In human organism it plays numerous roles of essentials importance. Due to its physicochemical properties, intracellular magnesium can bind to the nucleus, ribosomes, cell membranes or macromolecules occurring in the cell's cytosol. Being an activator of about 300 enzymes, magnesium takes part in plenty of metabolic pathways, such as: glycolysis, $\beta$-oxidation, Krebs cycle or ions' transport across cell membranes, which are very important, especially for a newly developing organism such as a newborn baby [53,54]. Because magnesium plays a key role in the regulation of functions of mitochondria and ATP production, the symptoms of its deficiency in newborns can lead to disturbances of muscles, lungs functions as well as to disturbances of cardiovascular and gastrointestinal systems. The dietary requirement for magnesium in infants is 40-60 mg/day whereas in children $80-170 \mathrm{mg} /$ day (Tab.5) [52,54].

Potassium $(\mathrm{K})$, sodium $(\mathrm{Na})$ and chlorine $(\mathrm{Cl})$ are electrolytes responsible for water, electrolyte and acid-base management in the body. They are an essential component of parenteral nutrition. They should be used in accordance with daily requirements and current serum concentration. Their concentration in the blood serum of newborn babies born prematurely, should be controlled daily for the first 3-7 days of life or more frequently [8, 51, $54,56,57]$. Sodium is the main electrolyte of extracellular fluids, whereas potassium is primarily found inside the cells. These elements are responsible for the exchange of substances through the cell membrane and the spread of electrical stimuli in the nerve fibers $[7,51,56,57]$.

The potassium is the main cation of the intracellular space, being a sodium antagonist and its opposite action is based on the reducing the volume of extracellular fluids, which helps to control the amount of water in the body. Potassium, being also a calcium antagonist, is responsible for proper muscle tone (tonus), by regulating the potential of cell membranes and the excitability of nerve and muscle cells. The dietary potassium requirement increases in age-dependent way and is equal: in infants 400-1200 mg/day, in children below 7 years of age 550-2500 mg/day, in older children $1000-4500 \mathrm{mg} /$ day (Tab.5) [52, 57].

Sodium is the most important extracellular cation. It is responsible for maintaining the osmotic pressure and regulating the acid-base economy. Sodium is involved in regulating the permeability of cell membranes and affects the maintenance of normal neuromuscular excitability. It is mainly excreted in the urine and through the skin. The daily requirement for this element depends on age and is equal to: $120-750 \mathrm{mg}$ /day in infants; $320-1350 \mathrm{mg} /$ day in children under 7 years of age; $600-2700 \mathrm{mg}$ /day in older children (Tab.5) [56, 57].

Chlorine is an anion of extracellular space, in the human body it is in the form of chloride anion (negative ion), mainly in extracellular fluids (including blood plasma), in the stomach as a component of hydrochloric acid, and in saliva. It is also found in the skin, subcutaneous tissue and bones [51, 53]. Chlorine, like sodium and potassium, regulates waterelectrolyte and acid-base balance and activates digestive enzymes of saliva (including salivary amylase) and participates in the production of hydrochloric acid in the stomach [52, 54].

\section{Microelements}

Trace elements are elements that together account for less than $0.01 \%$ of the total body weight. These include: iron, iodine, chromium, zinc, copper, selenium, molybdenum, manganese and fluorine. These are important elements that are involved in many metabolic processes. In children, who are fed parenterally, trace elements should always be added to nutrient mixtures at a daily dose. In the case of detecting deficiencies of specific elements, for example due to severe diarrhea or fistulas of the gastrointestinal tract, the nutrient mixture is 
enriched with additional amounts of individual elements in the form of separate preparations $[8,51,54]$.

Chromium $(\mathrm{Cr})$ is an essential element involved in the metabolism of carbohydrates and lipids. This element is a part of the glucose tolerance factor (GFT-Glucose Tolerance Factor), which is needed for the proper metabolism of glucose, and enhances the action of insulin. Its dietary requirement increases in age-dependent way from 10-60 mg/day in infants to $50-200 \mathrm{mg} /$ day in adults (Tab. 5) [51, 54, 58].

Copper $(\mathrm{Cu})$ is an important component of many enzymes. It is a part of superoxide dismutase, an antioxidant enzyme that protects cell membranes against free radicals. Copper is needed for the formation of red blood cells, it participates in the synthesis of connective tissue and plays an important role in the synthesis of prostaglandins, and therefore has an influence on the work of the heart and blood pressure. The deficit of copper can result in impaired energy production, abnormal glucose and cholesterol metabolism, increased oxidative damage and increased tissue iron $(\mathrm{Fe})$ accrual. The dietary requirement increases in age-dependent way and ranges from $0.4-0.7 \mathrm{mg} /$ day in infants to $1.5-3.0 \mathrm{mg} /$ day in adults (Tab. 6) [2, 8, 52, 53, 54].

Iodine (I) is an essential element, which builds the thyroid hormones: thyroxine and triiodothyronine. Both of these hormones are necessary in regulating the metabolism of the body. Its dietary requirement depends on age and intensity of metabolic processes. It is: $40-50$ $\mathrm{mg} /$ day in infants and about $150 \mathrm{mg} /$ day in adults (Tab. 5) [53, 54, 59].

Manganese $(\mathrm{Mn})$ is part of many enzymes, such as superoxide dismutase, and activates some hydrolases, kinases or transferases. The dietary requirement for this element changes depending on age and state of health. It ranges from 0.3 to $1.0 \mathrm{mg} /$ day in infants (Tab. 5) $[6,51,52,54]$.

Molybdenum (Mo) is a synergy for enzyme function and enzymes involved in DNA metabolism. The dietary requirement increases in age-dependent way and ranges from 15-40 $\mathrm{mg}$ /day in infants to 75-250 $\mathrm{mg}$ /day in adults (Tab. 5) [53, 54, 59].

Selenium (Se) is an ingredient in many enzymes, such as: glutathione peroxidase, which is an antioxidant that protects cell membranes from the damaging effects of oxygen free radicals. Selenium is essential for the proper synthesis, activation of thyroid hormones and decompression of the immune system. The dietary requirement for this element ranges from 10-15 mg/day in infants to 40-70 mg/day in adults (Tab. 5) [1, 54, 59, 60].

Zinc (Zn) affects all basic life processes, such as the metabolism of proteins, carbohydrates, fats. It participates in energy processes and nucleic acid metabolism, is a part of many enzymes and plays an important role in bone mineralization, wound healing and immune system function. Newborn babies born prematurely have an increased need for this mineral compared to those born at time $[53,54,58]$. The dietary requirement for zinc is as follows: in newborns $5-10 \mathrm{mg} /$ day, in adults $12-15 \mathrm{mg} /$ day. In women during lactation is increased up to $19 \mathrm{mg} /$ day (Tab. 5) [53,58].

Newborn babies born prematurely are particularly at risk of deficiency of the abovementioned microelements, due to the shorter pregnancy period and due to the increased demand of these substances, especially in the final stage of pregnancy. In the case of longterm parenteral nutrition, trace elements should be administered and periodically monitored in the child's body $[4,51,53]$. 
Table 5. Mineral ingredients dose in parenteral nutrition in newborns $[52,53,54]$.

\begin{tabular}{|c|c|c|c|c|c|c|c|}
\hline \multirow{3}{*}{$\begin{array}{l}\text { Macroelements } \\
\text { Dose } \\
\text { Microelements }\end{array}$} & \multicolumn{2}{|c|}{$\mathrm{Ca}^{2+}$} & \multicolumn{2}{|l|}{$\mathrm{Mg}^{2+}$} & $\mathbf{N a}^{+}$ & \multicolumn{2}{|c|}{$\mathbf{K}^{+}$} \\
\hline & $400-600$ & g/day & $40-60 \mathrm{mg}$ & & $750 \mathrm{mg} / \mathrm{d}$ & $400-$ & $0 \mathrm{mg} / \mathrm{day}$ \\
\hline & $\mathrm{Cr}^{2+}$ & $\mathrm{Cu}^{2+}$ & $\mathbf{I}^{+}$ & $\mathrm{Mn}^{2+}$ & $\mathrm{Mo}^{+4}$ & $\mathrm{Se}^{2+}$ & $\mathrm{Zn}^{2+}$ \\
\hline Dose & $\begin{array}{c}10 \\
\mathrm{mg} / \text { day }\end{array}$ & $\begin{array}{l}0.4-0.7 \\
\mathrm{mg} / \text { day }\end{array}$ & $\begin{array}{c}40-50 \\
\mathrm{mg} / \text { day }\end{array}$ & $\begin{array}{l}0.3-1.0 \\
\mathrm{mg} / \text { day }\end{array}$ & $\begin{array}{c}15-40 \\
\mathrm{mg} / \text { day }\end{array}$ & $\begin{array}{c}10-15 \\
\mathrm{mg} / \text { day }\end{array}$ & $\begin{array}{c}5-10 \\
\mathrm{mg} / \text { day }\end{array}$ \\
\hline
\end{tabular}

Summary

Parenteral nutrition of children must provide the proper nutrition status and allows the correct somatic growth $t$ and the development of the central nervous system. It provides all necessary nutrients: proteins, carbohydrates, fats, electrolytes, vitamins, trace elements and water via the intravenous route and will be effective only when all nutrients are given to the child in appropriate proportions [37, 38, 41]. Lack or deficiency of any of them prevents the effective use of others. The need for individual nutrients in a pediatric patient is individual. It depends on age, sex, comorbidities, and the initial state of nutrition. Proper planning of parenteral nutrition of a child consists not only in the calculation of the need for individual nutrients, but also in the selection of a specific, most suitable for the patient preparation $[2,7$, $11,16,37]$.

\section{References}

1. Paltrinieri AL, Cheng I, Chitrit M, Turnock K. Parenteral nutrition is not a fluid! Arch. Dis. Child Educ. Pract. Ed. 2016 Oct;101(5):252-257.

2. Hulst J, Joosten K, Zimmermann L, Hop W, van Buuren S, Büller H et al.: Malnutrition in critically ill children: from Israelite J. Pediatric Parenteral NutritionAssociated Liver Disease. J. Infus. Nurs. 2017 Jan/Feb;40(1):51-54.

3. Fallon EM, Nehra D, Potemkin AK, Gura KM, Simpser E, Compher C; American Society for Parenteral and Enteral Nutrition (A.S.P.E.N.) Board of Directors, Puder M. A.S.P.E.N. clinical guidelines: nutrition support of neonatal patients at risk for necrotizing enterocolitis. JPEN J Parenter Enteral Nutr. 2012 Sep;36(5):506-23.

4. Lenclen R, Crauste-Manciet S, Narcy P, Boukhouna S, Geffray A, Guerrault MN, et. al. Assessment of implementation of a standardized parenteral formulation for early nutritional support of very preterm infants. Eur. J. Pediatr. 2006;165:512-518.

5. Poindexter BB, Denne SC. Parenteral nutrition. Avery's diseases of the newborn. Elsevier Saunders 2012;963-971.

6. Simmer K., Rakshasbhuvankar A., Deshpande G. Standardised parenteral nutrition. Nutrients. 2013 Mar 28;5(4):1058-1070.

7. Mehta NM, Corkins MR, Lyman B, Malone A, Goday PS, Carney LN, Monczka JL, Plogsted SW, Schwenk WF; American Society for Parenteral and Enteral Nutrition Board of Directors. Defining pediatric malnutrition: a paradigm shift toward etiology-related definitions. JPEN J Parenter. Enteral. Nutr. 2013 Jul;37(4):460-81.

8. Bechard LJ, Parrott JS, Mehta NM: Systematic review of the influence of energy and protein intake on protein balance in critically ill children. Journal Pediatric. 2012; 161 : $333-339$.

9. Denne S, Poindexter B. Evidence supporting early nutritional support with parenteral amino acid infusion. Seminars in Perinatology 2007;31:56-60.

10. Verbruggen SC, Schierbeek H, Coss-Bu J, Joosten KF, Castillo L, van Goudoever JB.: Albumin synthesis rates in postsurgical infants and septic adolescents; influence of amino acids, energy, and insulin. Clin. Nutr. 2011;30: 469-477.

11. Chhim RF, Crill CM. Premixed Parenteral Nutrition Solution Use in Children. J Pediatr. Pharmacol. Ther. 2015 Sep-Oct;20(5):378-384. 
12. Fivez T, Kerklaan D, Mesotten D, Verbruggen S, Joosten K, Van den Berghe G. Evidence for the use of parenteral nutrition in the pediatric intensive care unit. Clin. Nutr. $2017 \mathrm{Feb} ; 36(1): 218-223$.

13. Goulet O, Jochum F, Koletzko B. Early or Late Parenteral Nutrition in Critically Ill Children: Practical Implications of the PEP a NIC Trial. Ann. Nutr. Metab. 2017;70(1):34-38.

14. Beken S, Dilli D, Fettah ND, Kabataş EU, Zenciroğlu A, Okumuş N.: The influence of fish-oil lipid emulsions on retinopathy of prematurity in very low birth weight infants: a randomized controlled trial. Early Hum. Dev. 2014;90: 27-31.

15. Wales PW, Allen N, Worthington P, George D, Compher C; American Society for Parenteral and Enteral Nutrition, Teitelbaum D. A.S.P.E.N. clinical guidelines: support of pediatric patients with intestinal failure at risk of parenteral nutrition-associated liver disease. JPEN J Parenter. Enteral. Nutr. 2014 Jul;38(5):538-57.

16. Salama GS, Kaabneh MA, Almasaeed MN, Alquran MI. Intravenous lipids for preterm infants: a review. Clin Med Insights Pediatr. 2015 Feb 9;9:25-36.

17. Forchielli ML, Bonoli A, Preite I, Stancari A, Maselli S, Guarguaglini AM, et. al. Parenteral nutrition admixtures for pediatric patients compounded with highly refined fish oilbased emulsion: assessment of physicochemical stability. Clin. Nutr. 2014 Dec;33(6):11271131.

18. Nandivada P, Fell GL, Gura KM, Puder M. Lipid emulsions in the treatment and prevention of parenteral nutrition-associated liver disease in infants and children. Am J. Clin. Nutr. 2016 Feb;103(2):629-734.

19. Pawlik D, Lauterbach R, Walczak M, Hurkała J, Sherman MP: Fish-oil fat emulsion supplementation reduces the risk of retinopathy in very low birth weight infants: a prospective, randomized study. J Parenter. Enteral. Nutr. 2014;38:711-716.

20. Savini S, D’Ascenzo R, Biagetti C, Serpentini G, Pompilio A, Bartoli A: The effect of 5 intravenous lipids emulsions on plasma phytosterols in preterm infants receiving parenteral nutrition: a randomized clinical trial. Am J Clin. Nutr. 2013;98:312-318.

21. Wanten GJ, Calder PC. Immune modulation by parenteral lipid emulsions. Am J Clin. Nutr. 2007;85:1171-1184.

22. Gobel Y, Koletzko B, Bohles HJ, Engelsberger I, Forget D, Le Brun A et. al.: Parenteral fat emulsions based on olive and soyben oil: a randomized clinical trial in preterm infants. Journal of Pediatr. Gastrol. Nutr. 2003;37: 161-167.

23. Gura KM, Lee S, Valim C, Zhou J, Kim S, Modi BP et. al.: Safety and efficacy of a fish-oil-based fat emulsion in the treatment of parenteral nutrition- associated liver disease. Pediatrics 2008;121: 678-686.

24. Druyan ME, Compher C, Boullata JI, Braunschweig CL, George DE, Simpser E, Worthington PA; American Society for Parenteral and Enteral Nutrition Board of Directors. Clinical Guidelines For the Use of Parenteral and Enteral Nutrition in Adult and Pediatric Patients: applying the GRADE system to development of A.S.P.E.N. clinical guidelines. JPEN J Parenter. Enteral. Nutr. 2012 Jan;36(1):77-80.

25. Heird WC. The role of essential fatty acids in development. W: Thureen PJ, Hay Neonatal Nutrition and Metabolism, second edition 2006;147-160.

26. Arsenault D, Brenn M, Kim S, Gura K, Compher C, Simpser E et.al. American Society for Parenteral and Enteral Nutrition Board of Directors, Puder M. A.S.P.E.N. Clinical Guidelines: hyperglycemia and hypoglycemia in the neonate receiving parenteral nutrition. J. Parenter. Enteral. Nutr. 2012;36:81-95.

27. Coss-Bu JA, Klish WJ, Walding D, Stein F, Smith EO, Jefferson LS: Energy metabolism, nitrogen balance, and substrate utilization in critically ill children. Am J. Clin. Nutr. 2001;74: 664-669.

28. Faustino EV, Apkon M: Persistent hyperglycemia in critically ill children. J. Pediatr. 
2005;46: 30-34.

29. Kao LS, Morris BH, Lally KP, Stewart CD, Huseby V, Kennedy KA. Hyperglycemia and morbidity and mortality in extremely low birth weight infants. J. Perinatol. 2006;26:730736.

30. Hays SP, Smith EO, Sunehag AL. Hyperglycemia is a risk factor for early death and morbidity in extremely low birth-weight infants. Pediatrics 2006;118:1811- 1818.

31. Klein GW, Hojsak JM, Rapaport R: Hyperglycemia in the pediatric intensive care unit. Curr. Opin. Clin. Nutr. Metab. J. Pediatr. 2008 Sep;153(3):379-384.

32. Ziegler E. Meeting the nutritional needs of the low-birth weight infant. Ann. Nutr. Metab. 2011;58(suppl 1):8-18.

33. Puntis JWL. Paediatric parenteral nutrition. In Artificial Nutrition Support in Clinical Practice 2002, 2nd ed: 461-484.

34. Mahgoub L.O.E., Puntis J.W.L. Long-term parenteral nutrition. Current Pediatrics 2006;16: 298-304.

35. Książyk J. European recommendations for parenteral nutrition of children, Contemporary Pediatrics. Gastroenterology. Hepatology and Child Nutrition 2006;8(3):19200.

36. Mactier H, Mokaya MM, Farrell L, Edwards CA. Vitamin A provision for preterm infants: are we meeting current guidelines? Archives of Disease in Childhood-Fetal and Neonatal Edition 2011;96:286-289.

37. Porcelli PJ, Greene H, Adcock E. A modified vitamin regimen for vitamin B2, A, and E administration in very-low-birth-weight infants. J. Parenter. Enteral. Nutr.2004;38:392400 .

38. Płudowski P, Karczmarewicz E, Bayer M, Carter G, Chlebna-Sokół D, CzechKowalska J et al.: Practical guidelines for the supplementation of vitamin D and the treatment of deficits in Central Europe - recommended vitamin D intakes in the general population and groups at risk of vitamin D deficiency. Endocrinol. Pol. 2013;64:319-327.

39. Czech-Kowalska J, Dobrzańska A. Practical aspects of vitamin D supplementation. Nutr. Metab. Care. 2017 May;20(3):227-231.

40. Czech-Kowalska J, Dobrzańska A. Prevention of bleeding from vitamin K deficiency in the neonatal and infancy period. Standards Med. 2007;4:2004-2010.

41. Clarke P, Mitchell SJ, Wynn R, Sundaram S, Speed V, Gardener E et al.: Vitamin K prophylaxis for preterm infants: a randomized, controlled trial of 3 regimens. Pediatrics 2006;118:1657-1666.

42. Clarke P. Vitamin K prophylaxis for preterm infants. Early Hum. Dev. 2010;86(Suppl 1):17-20.

43. Bigioni F, Verlato G, De Lorenzi L, Frigo AC, Gaio P, Di Lenardo E, Bertazzo A, Chiandetti L. Assessment of standardised parenteral nutrition in paediatrics. Eur. J. Clin. Nutr. 2014 Apr;68(4):535-536.

44. Watrobska-Swietlikowska D, Szlagatys-Sidorkiewicz A, Łuszkiewicz K. Evaluation of physical stability of all in one parenteral admixtures for pediatric home care with high electrolytes concentrations. Nutr. Hosp. 2014 Jan 1;31(1):236-243.

45. Wong T. Parenteral trace elements in children: clinical aspects and dosage recommendations. Curr. Opin. Clin. Nutr. Metab. Care. 2012 Nov;15(6):649-656.

46. Slicker J, Vermilyea S. Pediatric parenteral nutrition: putting the microscope on macronutrients and micronutrients. Nutr. Clin. Pract. 2009 Aug-Sep;24(4):481-486.

47. MacKay M, Jackson D, Eggert L, Fitzgerald K, Cash J. Practice-based validation of calcium and phosphorus solubility limits for pediatric parenteral nutrition solutions. Nutr. Clin. Pract. 2011 Dec;26(6):708-713. 
48. Mulla S, Stirling S, Cowey S, Close R, Pullan S, Howe R, Radbone L, Clarke P. Severe hypercalcaemia and hypophosphataemia with an optimised preterm parenteral nutrition formulation in two epochs of differing phosphate supplementation. Arch. Dis. Child Fetal Neonatal. Ed. 2017 Sep;102(5):451-455.

49. Johnsen JC, Reese SA, Mackay M, Anderson CR, Jackson D, Paul IL. Assessing Selenium, Manganese, and Iodine Status in Pediatric Patients Receiving Parenteral Nutrition. Nutr. Clin. Pract. 2017 Aug;32(4):552-556.

50. Etani Y, Nishimoto Y, Kawamoto K, Yamada H, Shouji Y, Kawahara H, Ida S. Selenium deficiency in children and adolescents nourished by parenteral nutrition and/or selenium-deficient enteral formula. J. Trace Elem. Med. Biol. 2014 Oct;28(4):409-413.

51. Arrowsmith F, Allen J, gaskin k, Somerville H, Clarke S, OlLoughlin E. The effect of gastrotmy tube feeding on body protein and bone mineralization in children with cerebral palsy. Dev Med Child Neurol, 2010, 52, 1043-1047.

52. Szlagatys-Sidorkiewicz A, Popińska K, Toporowska-Kowalska E, Borkowska A, Sibilska M, Gębora- Kowalska B at all. Home enteral nutrition I children - 2010 nationwide survey of the Polish Society for Clinical Nutrition of Children. Eur J Pediatr. 2011 Dec 15.

53. Braegger C, Decsi T, Dias J, Hartman C, Kolacek S, Koletzko B. at all. ESPGHAN Committee on Nutrition:. Practical approach to paediatric enteral nutrition: a comment by the ESPGHAN committee on nutrition. J Pediatr Gastroenterol Nutr. 2010; 51:110-22.

54. Toporowska-Kowalska E, Gębora-Kowalska B, Jabłoński J, Fendler W, WąsowskaKrólikowska K: Influence of percutaneous endoscopic gastrostomy on gastro-oesophageal reflux evaluated by multiple intraluminal impedance in children with neurological impairment Dev Med Child Neurol. 2011; 53:938-943.

55. Braegger C., Decsi T., Dias J.A., Hartman C., Kolacek S., Koletzko B. At.all. ESPGHAN Committee on Nutrition: Practical approach to paediatric enteral nutrition: a comment by the ESPGHAN Committee on Nutrition. J. Pediatr. Gastroenterol. Nutr., 2010, 51, $110-122$.

56. Ojo O.: Home enteralnutrition NICE guidelines andnutrition support inprimary care. Br. J. Community Nurs., 2010, 5, 116-118, 120.

57. Merritt RJ, Goldsmith AH. Scientific, economic, regulatory, and ethical challenges of bringing science-based pediatric nutrition products to the U.S. market and ensuring their availability for patients. JPEN J Parenter Enteral Nutr. 2014 Nov;38(2 Suppl):17S-34S.

58. Gallagher K, Flint A, Mouzaki M, Carpenter A, Haliburton B, Bannister L at all. Nutrition Diet Study: Feasibility, Clinical, and Microbiome Outcomes of Providing Blenderized Feeds Through a Gastric Tube in a Medically Complex Pediatric Population. JPEN J Parenter Enteral Nutr. 2018 Jan 16.

59. Caselli TB, Lomazi EA, Montenegro MAS, Bellomo-Brandao MA. Comparative study on gastrostomy and orally nutrition of children and adolescents with tetraparesis cerebral palsy. Arq Gastroenterol. 2017 Dec;54(4):292-296.

60. Vanhorebeek I, Verbruggen S, Casaer MP, Gunst J, Wouters PJ, Hanot J at. All.. Effect of early supplemental parenteral nutrition in the paediatric ICU: a preplanned observational study of post-randomisation treatments in the PEPaNIC trial. Lancet Respir Med. 2017 Jun;5(6):475-483. 